\title{
Induction of Plantlet Regeneration on Shallot (Allium cepa var. Aggregatum)
}

\author{
M. Marlin*, M. Handajani, Y. Yulian, R. Rustikawati, R. Herawati \\ Department of Crop Production, Faculty of Agriculture, University of Bengkulu, Bengkulu 38371, Indonesia \\ *Corresponding author. Email: marlin@unib.ac.id
}

\begin{abstract}
Micropropagation is an alternative method for producing pathogenic contamination-free shallots seedlings. The aim of this research was to determine the optimum balance of auxin-cytokinin and sucrose concentration in stimulating the plantlet regeneration on shallot. The research was conducted from March to August 2019. In this study, the auxin and cytokinin treatment (1-5 ppm) were used in the format of a randomized complete block design in three replications. The basal plate containing a shoot bud was excised from healthy bulb and used as planting material. The explants had been through a sterilization process and was cultured aseptically in medium containing each treatment. Culture medium contained 7 g. $\mathrm{L}^{-1}$ agar powder and were adjusted at $\mathrm{pH}$ 5.8 before autoclaving. The multiple shootlet (10 weeks of cultured) were then subcultured for bulblet formation in MS medium supplemeted with BAP dan succrose (3-9\%). The basal plate containing a shoot bud was excised from healthy bulb and used as planting material. The explants had been through a sterilization process and was cultured aseptically in medium containing each treatment. Culture medium contained $7 \mathrm{~g} \mathrm{~L}^{-1}$ agar powder and were adjusted at $\mathrm{pH} 5.8$ before autoclaving. The results showed that the use of $1 / 2 \mathrm{MS}$ media could increase the efficiency of using nutrient solution of tissue culture media. Micro shoot formation can be initiated on $1 / 2$ MS medium with the addition of 1 ppm BAP (1.36 shoots / explants). This media also produced the best response for the number of micro roots (5.63 roots / explants), and the number of micro leaves (3.91 leaves). However, the difference in composition of nutrient in culture media was not able to accelerate the time of growth of shoots, roots and leaves. Further subculture in $1 / 2$ strength of MS medium containing of BAP and sucrose 6\% increased shoot, root and bulblet formation (13.3 shoots, 41.3 roots and 10.7 bulblets).
\end{abstract}

Keywords: Allium cepa var. Aggregatum, micropropagation, MS medium, NAA, sucrose

\section{INTRODUCTION}

Shallots (Allium cepa var. aggregatum) are plants from the Allium group which have many benefits with complex metabolite compounds. A total of 88 specific metabolites were found in vernalized bulb of shallot [1]. The composition metabolites from 5 genotypes were the difference and suggested correlated to flowering competency [2]. Shallots can be used as food, spices and medicines. Shallots contain chemical compounds that can function as anti-inflammatory, anti-cholesterol, anti-cancer and antioxidant [3].

Shallot propagation can be done by vegetative and generative method. Propagation by vegetative method using vegetative bulb is more often done by farmers than by generative method using botanical seeds (true shallot seeds). Vegetatively propagation using bulbs causes pathogenic intrusion from the parent which is always carried on to the next offspring. The use of quality and pathogen-free seeds is needed to produce high productivity.
An alternative effort to improve the properties of shallot can be done by propagating plants using tissue culture techniques. Tissue culture technique is an efficient technique for clonal propagation due to high level of multiplication, quality plant material, more homogeneous, genetically the same as the parent, can be obtained in a relatively short time [4]. Through plant tissue culture techniques, a uniform planting material will be produced and free from pathogen contamination.

The tissue culture technique in the Allium group generally resulted in shoot formation from organogenic callus formation. Dixit [5] reported micro shoots (3-4 shoots) of garlic had been obtained from callus culture on the media with the addition of BAP or BAP combined with NAA. While Kurniawan and Widoretno [6] showed that the addition of 2,4-D to culture media was able to induce callus formation on explants, the addition of kinetin combined with NAA in the medium was able to induce onion shoots from callus explants. Khar et al. [7] had regenerated micro shoots of Allium cepa using kinetin $2 \mathrm{mg} / \mathrm{L}$. This medium showed better results with induction of 5-8 shoots in the callus, 
while the use of BAP resulted in albino bud growth with chlorophyll deficiency. However, the increase in kinetin concentration in the media can inhibit shoot emergence time Allium cepa callus explants [8]. The formation of micro shoots (1-2.1 shoots per explant) in the media with the addition of BAP (0.9 to $4.4 \mathrm{Mm}$ ), while the media with the addition of kinetin $(10.6 \mu \mathrm{M})$ resulted in 1.9-2,1 micro shoot [9]. Giving BA in the media only produced 1 micro shoot per explant, whereas giving kinetin produced 1.5 micro shoots per explant [10]. Micropropagation is advantageous over traditional propagation as it can be used to multiply novel plants. Additional of balancing auxin-cytokinin, and sucrose were important to enhance in vitro plantlet regeneration of shallot.

This research aimed to determine the optimum balance of auxin-cytokinin and sucrose concentration in stimulating the plantlet regeneration on shallot.

\section{MATERIALS AND METHODS}

\subsection{Preparation of Explant}

Fresh and healthy bulbs were washed in tap water and detergent in order to clean the soils and some contaminants from the bulbs. The outer dry scales were peeled off and rejected. The cleaned bulbs were then treated with sterile water containing $20 \%$ bleach for 15 minutes with continuous agitation and finally rinsed three times with distilled water. The bulbs were washed thoroughly and immersed in $70 \%$ alcohol for 1-2 min, rinsed three times in distilled water, The explants which were excised from the bulbs were inoculated in Murashige and Skoog (1962) medium (MS medium)[11] containing 3\% (w/v) sucrose and $0.7 \%(\mathrm{w} / \mathrm{v})$ agar. Before autoclaving, $\mathrm{pH}$ was adjusted to 5.7. All media were autoclaved at $121^{\circ} \mathrm{C}, 15$ psi for $15 \mathrm{~min}$. Cultures were incubated at room temperature of $20{ }^{\circ} \mathrm{C}$ and under fluorescent day light tubes emitting $3200 \mathrm{Lux}$ for $16 / 8$ $\mathrm{h}$ light/dark period.

\subsection{Plantlet Regeneration}

The explant was transferred aseptically in MS medium containing each treatments. Planlet regeneration medium was MS medium supplemented with combination of BAP and NAA as follow

$\mathrm{M}_{1}=$ full MS medium with $1 \mathrm{ppm}$ BAP

$\mathrm{M}_{2}=$ full MS medium with $1 \mathrm{ppm} \mathrm{BAP}+1 \mathrm{ppm}$ NAA

$\mathrm{M}_{3}=1 / 2$ strength MS with $1 \mathrm{ppm}$ BAP

$\mathrm{M}_{4}=1 / 2$ strength MS with 1 ppm BAP + 1ppm NAA

$\mathrm{M}_{5}=1 / 2$ strength MS with 5 ppm BAP

$\mathrm{M}_{6}=1 / 2$ strength MS with 5 ppm BAP $+1 \mathrm{ppm}$ NAA

The experiment replicated 3 times with 6 explants per treatments. Cultured vials were incubated as explained above.

\subsection{Bulblet Induction}

The elongated shoots $(2-3 \mathrm{~cm})$ were rescued aseptically and transferred to bulblet induction medium containing $1 \mathrm{ppm}$ of BAP and $1 \mathrm{ppm}$ of NAA with various concentration of sucrose as follow:

$\mathrm{M}_{1} \mathrm{~S}_{1}=$ full MS medium with 1 ppm $\mathrm{BAP}+1 \mathrm{ppm} \mathrm{NAA}+$ $3 \%$ sucrose

$\mathrm{M}_{1} \mathrm{~S}_{2}=$ full MS medium with 1 ppm BAP + 1ppm NAA + $6 \%$ sucrose

$\mathrm{M}_{1} \mathrm{~S}_{3}=$ full MS medium with 1 ppm BAP +1 ppm NAA + $9 \%$ sucrose

$\mathrm{M}_{1} \mathrm{~S}_{4}=$ full MS medium with 1 ppm BAP +1 ppm NAA + $12 \%$ sucrose

$\mathrm{M}_{2} \mathrm{~S}_{1}=1 / 2$ strength $\mathrm{MS}$ with 1 ppm BAP +1 ppm NAA + $3 \%$ sucrose

$\mathrm{M}_{2} \mathrm{~S}_{2}=1 / 2$ strength MS with 1 ppm BAP +1 ppm NAA + $6 \%$ sucrose

$\mathrm{M}_{2} \mathrm{~S}_{3}=1 / 2$ strength MS with 1 ppm BAP + 1ppm NAA + $9 \%$ sucrose

$\mathrm{M}_{2} \mathrm{~S}_{4}=1 / 2$ strength $\mathrm{MS}$ with 1 ppm BAP +1 ppm NAA + $12 \%$ sucrose

The experiment replicated 3 times with 6 explants per treatments. The vials containing single plantlet were incubated as explained above. Day to day observation was carried out to note the response of the growing plantlets.

\subsection{Statistical Analysis}

All experiments were setup in the completely randomized design and data were analyzed using one-way analysis of variance (ANOVA) at the 5\% significance level.For mean comparison and statistical significant level pairwise LSD-test in all possible combination of he treatments was employed and mean comparison of experimental treatments by SAS software (Ver.9.1).

\section{RESULTS AND DISCUSSION}

\subsection{Plantlet Regeneration}

Micropropagation has also been effective in most species of Alliaceae including shallot. An established micropropagation protocol is not only important for the maintenance and mass production of commercially important cultivars but also in future research work in shallot breeding which include field testing and selection, disease elimination, germplasm collection, conservation and evaluation

Apical meristem, which usually belonged to the first or second section, developed further and formed apical shoot in all treatments. Actually, meristem parts were the only explants that responded by adventitious bud formation, therefore only these sections were used for treatments comparison. In this research we present a protocol for in vitro regeneration of shallot from bulbs. The treatment of composition of the nutrient showed a significant difference in the variable shoot number, plant height, roots number, and leaves number, and showed no significant effect on the variables of the days to growth shoot, root, nor leaf (Table $1)$. 
Table 1 The effect of nutrient composition on the growth of in vitro shallot explants

\begin{tabular}{|l|c|c|}
\hline Variable & F value & CV \\
\hline Days to leaves & $0.201 \mathrm{~ns}$ & 22.27 \\
\hline Days to root & $0.434 \mathrm{~ns}$ & 21.29 \\
\hline Day to shoot & $0.180 \mathrm{~ns}$ & 27.05 \\
\hline Shoot number & $10.993 * *$ & 19.10 \\
\hline Plant height & $4.267 * *$ & 36.46 \\
\hline Root number & $2.682 *$ & 18.90 \\
\hline Leaves number & $4.986 * *$ & 18.42 \\
\hline
\end{tabular}

$\mathrm{ns}=$ non significant effect at the $5 \%$ significance level of analysis of variance

$*=$ the $5 \%$ significance levelof analysis of variance

$* *=$ the $5 \%$ significance levelof analysis of variance

Further test with LSD test at 5\% level resulted that in full MS medium supplemented with 1 ppm BAP was promoted the highest of shoots number, plant height, roots number and leaves number compared to other treatments. There was no significant different effects on growth response of shallot explants on full MS medium supplemented with $1 \mathrm{ppm}$ and in $1 / 2 \mathrm{MS}$ medium supplemented with 1 ppm BAP singly or on medium with $1 / 2 \mathrm{MS}$ medium with the addition of $1 \mathrm{ppm}$ BAP and $1 \mathrm{ppm}$ NAA (Table 2 )

Table 2 The effect of nutrient composition on the growth medium to in vitro organogenesis of shallot explants

\begin{tabular}{|l|l|l|l|l|}
\hline Growth medium & $\begin{array}{l}\text { Shoot } \\
\text { number }\end{array}$ & $\begin{array}{l}\text { Plant } \\
\text { height }\end{array}$ & $\begin{array}{l}\text { Root } \\
\text { number }\end{array}$ & $\begin{array}{l}\text { Leaves } \\
\text { number }\end{array}$ \\
\hline Full MS hormone free & $0.71 \mathrm{~d}$ & $3.16 \mathrm{c}$ & $3.00 \mathrm{~b}$ & $1.41 \mathrm{~b}$ \\
\hline Full MS + 1 ppm of BAP & $1.49 \mathrm{ab}$ & $9.05 \mathrm{a}$ & $5.86 \mathrm{a}$ & $4.35 \mathrm{a}$ \\
\hline Full MS + 1 ppm of BAP + 1ppm of NAA & $1.67 \mathrm{a}$ & $6.62 \mathrm{ab}$ & $5.70 \mathrm{ab}$ & $4.30 \mathrm{a}$ \\
\hline $1 / 2 \mathrm{MS}+1$ ppm of BAP & $1.36 \mathrm{abc}$ & $5.15 \mathrm{bc}$ & $5.63 \mathrm{ab}$ & $3.91 \mathrm{ab}$ \\
\hline $1 / 2 \mathrm{MS}+1 \mathrm{ppm}$ of BAP + 1ppm of NAA & $0.71 \mathrm{~d}$ & $3.16 \mathrm{c}$ & $3.00 \mathrm{~b}$ & $1.41 \mathrm{~b}$ \\
\hline $1 / 2 \mathrm{MS}+5$ ppm of BAP & $1.10 \mathrm{c}$ & $5.66 \mathrm{bc}$ & $5.98 \mathrm{a}$ & $1.72 \mathrm{~b}$ \\
\hline $1 / 2 \mathrm{MS}+1$ ppm of BAP + 1ppm of NAA & $1.18 \mathrm{bc}$ & $5.17 \mathrm{bc}$ & $3.66 \mathrm{ab}$ & $1.79 \mathrm{~b}$ \\
\hline
\end{tabular}

Same letters within each column show no significant differences by least significant different test (LSD) at 5\% level.

These results indicated that shallot expant formed well-developed shoot on full MS medium or on $1 / 2$ MS medium. The highest shoot formation was obtained on MS medium with the addition 1 ppm BAP and 1 ppm NAA (1.67 shoots/plant). This response was not significantly different from shoot formation on MS medium with the addition 1 ppm BAP (1.49 shoots/plant) and on $1 / 2$ MS medium with the addition 1 ppm BAP (1.36 shoots/explant). The results of this study indicated that in vitro propagation of shallots can be enhanced by using half concentration of MS nutrient only. Thus, using $1 / 2 \mathrm{MS}$ basal medium may increase the efficiency of using nutrient solutions in shallot tissue cultures. This result is in line with the research on garlic plants which showed that garlic shoot growth could be carried out on $1 / 2$ MS medium [12].

In vitro shallot growth responses showed that root height, number of roots and number of leaves were increase during tissue culture period. The presence of auxin and cytokinin in medium culture increased explant growth and development. The presence of $1 \mathrm{ppm}$ BAP or addition of $1 \mathrm{ppm}$ BAP and $1 \mathrm{ppm}$ NAA increased explant growth in shallot tissue culture. The lowest shoot formation was occured in MS hormone free medium (MS 0 ) in Figure 1 as below.

The presence of plant growth regulator (BAP and NAA) is important to stimulate explant growth and develpoment on shallot micropropagation. Earlier report [13] showed an increase in percent shoot formation and number of shoot per explant was observed when the concentration of BAP+NAA was increased and in the current study it is also confirmed that cytokinins were the most determining hormones involved in the regeneration of shoots in shallot. The growth of garlic shoots was stimulated in medium culture with $0.5 \mathrm{ppm}$ BAP [12]. The addition of $0.5 \mathrm{ppm}$ BAP increased shoot growth in tissue culture of Tylophora indica [14]. 

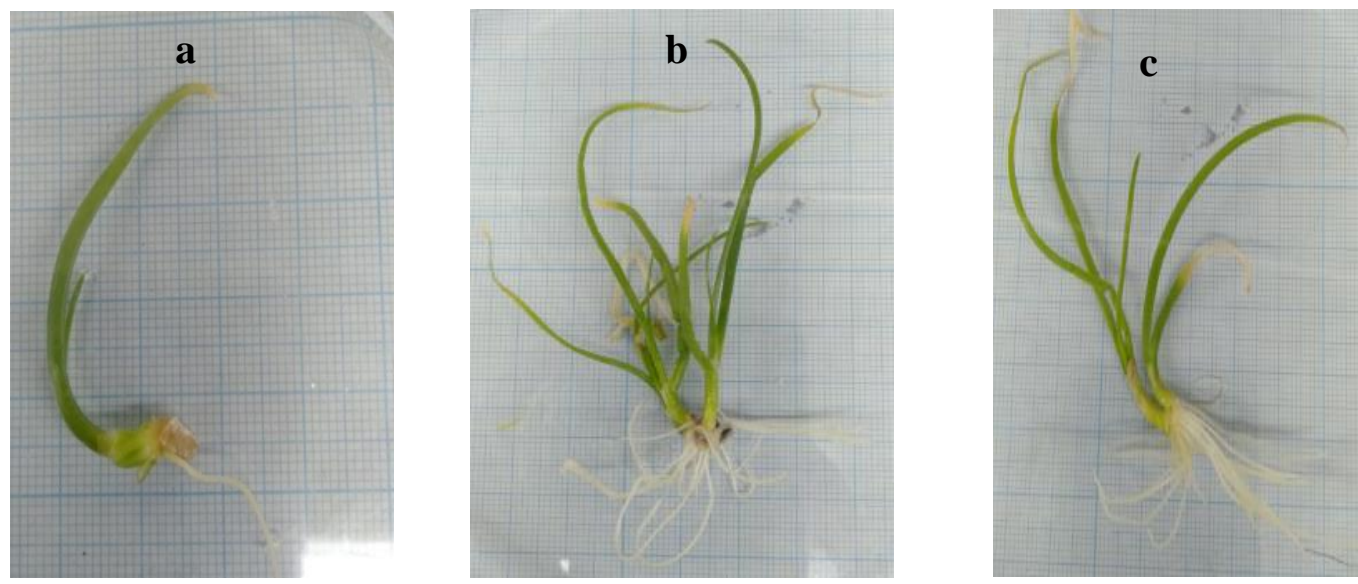

Figure 1. Plantlet formation on shallot tissue culture in different medium compositions. a) $M_{0}=M S$ hormone free medium, b) $\mathrm{M}_{1}=\mathrm{MS}$ medium supplemented with 1 ppm BAP, c) $\mathrm{M}_{2}=\mathrm{MS}$ medium suplemented with 1 ppm BAP and 1 ppm NAA

However, in this research showed that the high level of concentration of BAP (5 ppm) decreased the shoots number, plant height, root number and leaves number of shallots (Table 2). The higher concentration of BAP (5 ppm), the more declining plantlet regeneration in micropropagtion of shallot. It was also reported that addition of higher BAP actually inhibits shoot development of Tylophora indica[14]. It was contrary to the research of [15] that MS medium supplemented with 4 ppm BAP was able to accelerate the plantlets formation of shallot.
The effects nutrient composition in the culture medium have no significant effect on the variables of days to shoot, days to root, and days to sprout (Table 1). This results emphasized that the ability of explants to form shoots, roots and leaves occurred at the same time from all medium treatments. The addition of BAP and NAA in the planting medium, was not able to stimulus the formation of shoots, day to roots, and day to sprout. Thus, the ability of the explants to form shoots, roots and leaves was not significantly different, though they were grown in the different composition of the culture medium (Table 3 )

Table 3. The effect of nutrient solution composition treatment of culture medium on the growth of shallot explants in vitro

\begin{tabular}{|l|c|c|c|}
\hline Growth medium & Days to shoot & Days to root & Days to leaves \\
\hline Full MS hormone free & $3.77 \mathrm{a}$ & $3.82 \mathrm{a}$ & $4.04 \mathrm{a}$ \\
\hline Full MS + 1 ppm of BAP & $3.90 \mathrm{a}$ & $3.89 \mathrm{a}$ & $4.00 \mathrm{a}$ \\
\hline Full MS + 1 ppm of BAP + 1ppm of NAA & $3.95 \mathrm{a}$ & $4.40 \mathrm{a}$ & $4.07 \mathrm{a}$ \\
\hline $1 / 2 \mathrm{MS}+1 \mathrm{ppm}$ of BAP & $3.52 \mathrm{a}$ & $3.57 \mathrm{a}$ & $3.72 \mathrm{a}$ \\
\hline $1 / 2 \mathrm{MS}+1 \mathrm{ppm}$ of BAP + 1ppm of NAA & $3.80 \mathrm{a}$ & $3.79 \mathrm{a}$ & $3.92 \mathrm{a}$ \\
\hline $1 / 2 \mathrm{MS}+5 \mathrm{ppm}$ of BAP & $4.05 \mathrm{a}$ & $3.82 \mathrm{a}$ & $4.06 \mathrm{a}$ \\
\hline $1 / 2 \mathrm{MS}+1 \mathrm{ppm}$ of BAP + 1ppm of NAA & $4.08 \mathrm{a}$ & $4.18 \mathrm{a}$ & $4.50 \mathrm{a}$ \\
\hline
\end{tabular}

Same letters within each column show no significant differences by least significant different test (LSD) at $5 \%$ level

In medium containing BAP up to $10 \mathrm{ppm}$ had no significant effect on the shoots formation in ginger tissue culture [16]. This explains that the composition of nutrients and ZPT in the medium can increase plant growth and development, although it is not able to accelerate the initiation of shoot formation time, root growth time, and leaf appearance time.

\subsection{Bulblet Formation}

Subculturing plantlets to medium supplemented with sucrose induced bulblet formation in shallot (Figure 2). In MS half strength medium with $3-6 \%$ of sucrose enhanced bulblet growth and development. It was explained the function of sucrose as an energy and carbon source 


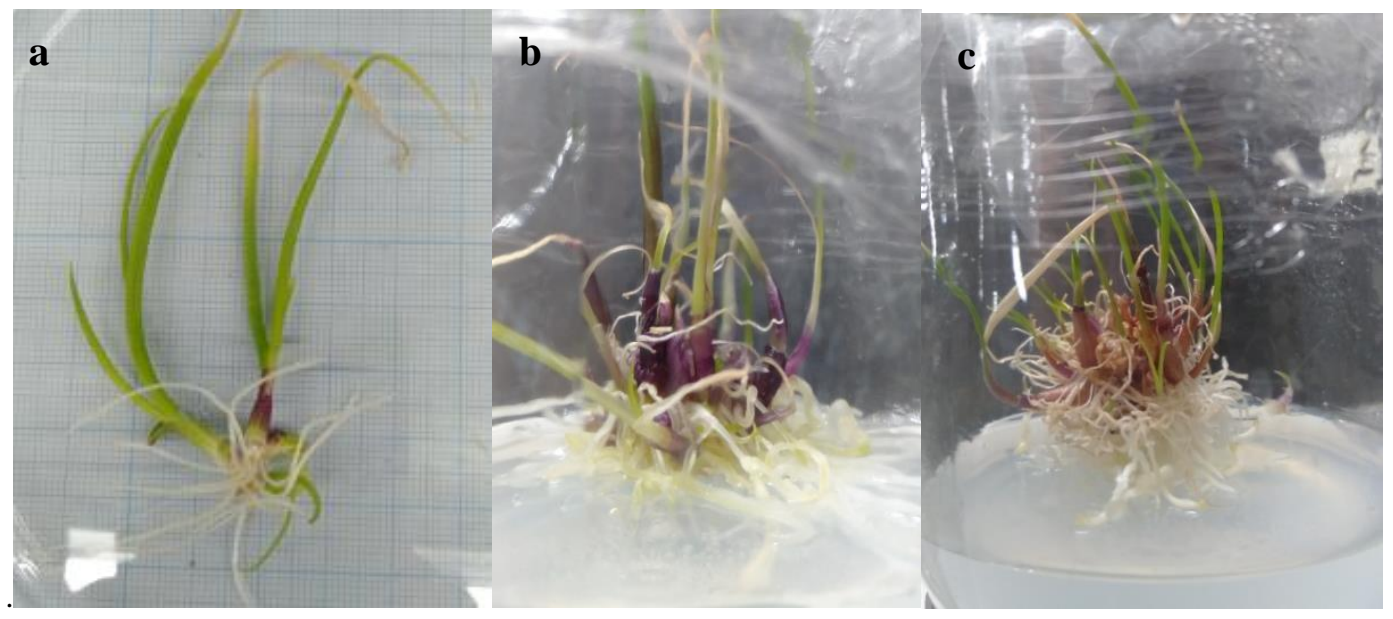

Figure 2. Bulblet formation of shallot micropropation.a) MS full strength medium with $3 \%$ of succrose, b) MS half strength medium with $3 \%$ of sucrose, and c) MS half strength medium with $6 \%$ of sucrose

Average bulblet number was 8 bulblets in MS half strength medium with $3 \%$ sucrose. Bulblets formation was increased in medium supplemented with sucrose of $6 \%$ (10.7 bulblets/explant). When sucrose, with a concentration of $6 \%$, was supplied to the culture medium of Lilium sargentiae, the bulblets could be most effectively induced and expanded[17].The important role of sucrose and plant growth regulators in multiplication rate and bulblet size in various bulbous crops was mentioned [18].

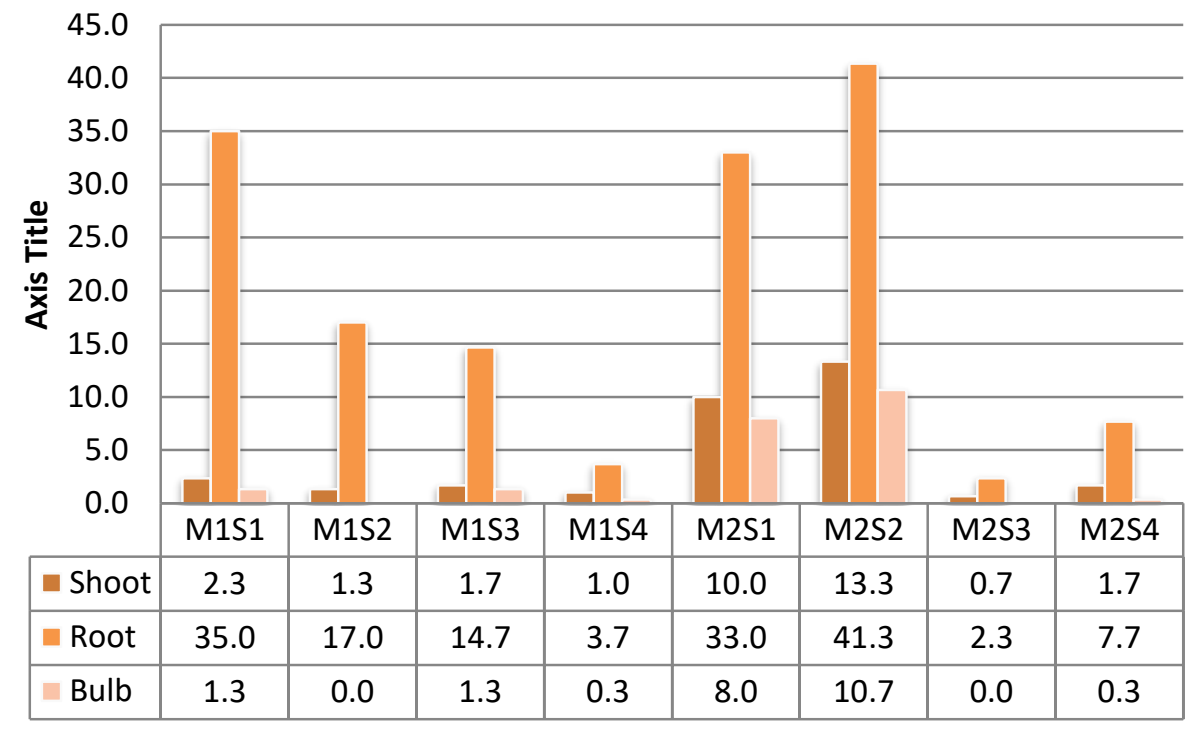

Figure 3. The effects of planting medium to shoot, root and bulb formation on shallot $\mathrm{M}_{1}=$ full MS medium supplemented with 1 ppm BAP + 1ppm NAA $\mathrm{M}_{2}=1 / 2$ strength $\mathrm{MS}$ supplemented with $1 \mathrm{ppm} \mathrm{BAP}+1 \mathrm{ppm}$ NAA $S_{1}=3 \%$ sucrose, $S_{2}=6 \%$ sucrose, $S_{3}=9 \%$ sucrose, and $S_{4}=12 \%$ sucrose

The effect of sucrose on the formation and expansion of $L$. sargentiae was obvious and dominant [17]. It was clear that using sucrose concentration above $3 \%$ in combination with paclobutrazol had a promotion effect on bulblets number[19].Acting as both carbon and energy source, exogenous sucrose was a key factor for bulblet formation[20].,

\section{CONCLUSION}

Plantlets regeneration of shallot can be initiated in $1 / 2$ MS medium supplemented with $1 \mathrm{ppm}$ BAP. The use of $1 / 2$ MS medium can increase the efficiency of using nutrient solution for tissue culture medium. In this medium produced the best response on the number of shoot (1.36 shoots/explant) and number of roots (5.63 roots / explants), and the number of leaves (3.91 pieces). 
However, the difference in composition of nutrient in culture media is not able to accelerate the time of growth of shoots, roots and leaves. Further subculture in $1 / 2$ strength of MS medium containing of BAP and sucrose $6 \%$ increased shoot, root and bulblet formation (13.3 shoots, 41.3 roots and 10.7 bulblets). These plantlets derived through tissue culture are considered a new source for shallot breeding and further in vitro research development.

\section{ACKNOWLEDGMENT}

This work was supported by PNPB Research Programe, Faculty of Agriculture, University of Bengkulu 2019.

\section{REFERENCES}

[1] M. Marlin, A. Maharijaya, A. Purwito, and S. Sobir. 'Secondary metabolites change under Vernalization and its relation to flowering Competency in shallot (Allium cepa var. aggregatum)', Rasayan Journal of Chemistry, vol. 12, no. 3, pp. 418-1425, 2019. Doi : http://dx.doi.org/10.31788/RJC.2019.1235356 (M. Marlin, 2019)

[2] Marlin, A.Maharijaya, Sobir, and A.Purwito. 'Metabolite Changes in Shallot (Allium cepa var. Agregatum) during Vernalization', Proceeding on International Seminar on Tropical Horticulture. Bogor Indonesia, pp. 125-130, 2016.

[3] C.R. Galmarini, IL Goldman, M.J..Havey. 'Genetic analyses of correlated solids, flavor, and healthenhancing traits in onion (Allium cepa L.)'. Molecular Genetetic and Genomics Vol. 265, pp. 543-551, 2001.

[4] S.S. Bhojwani, (ed.). 'Plant Tissue Culture: Applications and Limitations', Elsevier. Amsterdam, 1990.

[5] V. Dixit, S. P. Rai, and B. R. Chaudary, 'Allium sativum: Four-Step Approach to Efficient Micropropagation', Int. J. Innov. Biol. Res. vol. 2 No. 1, pp. 6-14, 1990.

[6] A.D. Kurniawan, and W. Widoretno, 'In vitro regeneration on shallot (Allium ascalonicum L.)' Jurnal Biotropika, Vol. 4, no. 1, pp. 1-4, 2016

[7] A. Khar, B. Ramdhan, Y. Neelam, and V.K. Chowdhury, 'Effect of explant and genotype on callus culture and Regeneration in onion ( Allium cepa 1.)', Akdeniz üniversitesi ziraat fakültesi dergisi, Vol. 18, no. 3, pp. 397-404, 2005.

[8] B.Hailekidan, M. Andargie, and K. Assefa, 'In vitro plantlet regeneration from the bulbs of shallot (Allium cepa Var. Group Aggregatum), Research in Plant Sciences, Vol. 1, no. 2, pp. 45-52, 2013.
[9] D. Kamstaityte, and V. Stanys, 'Micropropagation of onion (Allium cepa L.)', Acta Universitatis Latviensis, Biology, Vol. 676, pp. 173-176, 2005.

[10] R. Kahane, M.Rancillac, and B. Teyssendier, 'Longterm multiplication of onion (Allium cepa L.) by cyclic shoot regeneration in vitro', Plant Cell Tissue Organ Cult. Vol. 28, pp. 281-288, 1992.

[11] T. Murashige, and F. Skoog, 'A revised medium for rapid growth and bioassays with tobacco tissue cultures', Physiol. Plant, Vol. 15, pp. 473-497, 1962. onion (Allium cepa L.) in in-vitro', Pak.J. Biol. Sci. Vol. 4, no. 3, pp. 374-377, 2001.

[12] N. Khan, M. Fayyaz, Chaudhary, A.M. Abbasi, S.A Khan, A. Nazir, and G.M Shah, 'Development of an efficient callus derived regeneration system for garlic (Allium sativum L.) from root explant', Journal of Plant Breeding and Agriculture 1, Vol. 3, pp. 1-12, 2017.

[13] A. Khalid, D.Guo, and Z.J. Zhu, 'Effect of growth regulator on plantlet regeneration and bulbing in

[14] V. Soni, and M. Bhushan, 'Hormonal control of morphogenesis in vitro in nodal segments of Tylophora indica', Int. J. Life. Sci. Scienti. Res., Vol. 3, no. 4, pp. 1250-1252, 2017.

[15] Maemunah, R. Yusuf, S. Samudin, H. Kasim, and Yusran, 'Optimalization and regeneration of in vitro seedling of Shallot variety Lembah Palu in providing good quality seedling' IOP Conf. Series: Earth and Environmental Science, Vol. 235 2019.Doi:10.1088/1755-1315/235/1/012051

[16] Marlin, 'Plantlet regeneration of bacterial wilt-free ginger on medium supplemented with 6- Benzyl Amino Purine (BAP) and 1-Naphthalene Acetic Acid (NAA)' Jurnal Ilmu Pertanian Indonesia, Vol. VII, no. 1, pp. 8-14, 2005

[17] S. Gao, Y. Zhu, L. Zhou, 'Sucrose signaling function on the formation and swelling of bulblets of Lilium sargentiae E.H. Wilson', Plant Cell Tiss Organ Cult., Vol. 135. Pp. 143-153, 2018. https://doi.org/10.1007/s11240-018-1451-4

[18] M.L. Lian, H.N. Murthy, and K.Y. PaeK, 'Photoautotrophic culture conditions and photosynthetic photon flux influence growth of Lilium bulblets in vitro', In Vitro Cellular and Development Biology-Plant, Vol. 39, no. 5, pp. 532535, 2003

[19] L.S. Taha, N.M. Youssef, E.A. Ibrahim, and Z.F. Ghareeb, 'Tingitana bulblets production and chemical composition', Plant Archives Vol. 19, np. 2, pp. 2671-2676, 2019.

[20] X. Lü, D. Zhang, R. Min, S. Li, Z. Li, Z. Ren, and Y. Xia, 'Effects of exogenous sucrose on bulblet formation of lycorissprengeri in vitro', Acta Horticulturae Sinica. Vol. 47, no. 8, pp. 1475-1489, 2020 